\title{
Practical guidelines to ameliorate the effects of internal and external deployments on the marriages of soldiers
}

\begin{tabular}{|c|c|}
\hline \multicolumn{2}{|c|}{$\begin{array}{l}\text { Authors: } \\
\text { Velile E. Mtshayisa }{ }^{1} \text { (D) } \\
\text { Rantoa Letšosa }^{2} \text { (D) }\end{array}$} \\
\hline \multicolumn{2}{|c|}{$\begin{array}{l}\text { Affiliations: } \\
{ }^{1} \text { Department of Practical } \\
\text { Theology, Faculty of Theology, } \\
\text { North-West University, } \\
\text { Potchefstroom, South Africa }\end{array}$} \\
\hline \multicolumn{2}{|c|}{$\begin{array}{l}{ }^{2} \text { Faculty of Theology and } \\
\text { Religion, University of the } \\
\text { Free State, Bloemfontein, } \\
\text { South Africa }\end{array}$} \\
\hline \multicolumn{2}{|c|}{$\begin{array}{l}\text { Corresponding author: } \\
\text { Rantoa Letšosa, } \\
\text { letsosar@ufs.ac.za }\end{array}$} \\
\hline \multicolumn{2}{|c|}{$\begin{array}{l}\text { Dates: } \\
\text { Received: } 05 \text { July } 2019 \\
\text { Accepted: } 13 \text { Sept. } 2019 \\
\text { Published: } 04 \text { Nov. } 2019\end{array}$} \\
\hline \multicolumn{2}{|c|}{$\begin{array}{l}\text { How to cite this article: } \\
\text { Mtshayisa, V.E. \& Letšosa, R., } \\
\text { 2019, 'Practical guidelines to } \\
\text { ameliorate the effects of } \\
\text { internal and external } \\
\text { deployments on the } \\
\text { marriages of soldiers', } \\
\text { HTS Teologiese Studies/ } \\
\text { Theological Studies 75(4), } \\
\text { a5641. https://doi.org/ } \\
\text { 10.4102/hts.v75i4.5641 }\end{array}$} \\
\hline \multicolumn{2}{|c|}{$\begin{array}{l}\text { Copyright: } \\
\text { (C) 2019. The Authors. } \\
\text { Licensee: AOSIS. This } \\
\text { is licensed under the } \\
\text { Creative Commons } \\
\text { Attribution License. }\end{array}$} \\
\hline \multicolumn{2}{|l|}{ Read online: } \\
\hline 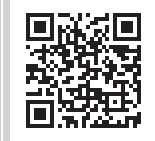 & $\begin{array}{l}\text { Scan this QR } \\
\text { code with your } \\
\text { smart phone or } \\
\text { mobile device } \\
\text { to read online. }\end{array}$ \\
\hline
\end{tabular}

This article critically looks at the challenges that are incumbent in the deployment of married soldiers who work for the South African National Defence Force (SANDF). The SANDF previously deployed soldiers outside the borders of South Africa for a period of 6 months or less. But currently, the SANDF has a deployment period of 12 months. This period is twice that of the earlier period, which means that soldiers and their families have to spend 12 months apart from one another. This has an adverse effect on the marriages of soldiers and makes the SANDF appear as an uncaring institute because its military operations tend to impact family lives. Using a qualitative research approach, this article explores the emic experiences of married soldiers who were deployed, and concludes by suggesting some pastoral guidelines that may prove useful for a multi-professional team handling the issues of deployment.

Keywords: deployment; soldiers; South African national defence force; marriage; peacekeeping.

\section{Introduction}

The Government of South Africa requested the South African National Defence Force (SANDF) in 1994 to take part in peacekeeping missions in Africa under the auspices of the United Nations to secure stability in war-torn African countries (Nibishaka 2011:3). The SANDF embarked on these peacekeeping missions because the parliament regarded participation as a non-negotiable objective and mandate (Pitse 2009:194). The periods the soldiers have to spend in the deployment areas are a challenge for the welfare of the soldiers and their respective families. Savych (2008) declares that deployment imposes a significant emotional burden on family members.

As this burden is out of the family's control, it increases the stress levels in the household.

Matjeke (2017:3) mentions that the SANDF previously deployed soldiers outside the borders of South Africa for a period of 6 months or less. Currently, the deployment period is 12 months, with a possible 2 weeks of leave in between. This period is twice that of the earlier period, which means that soldiers and their families have to spend 12 months apart from one another. Soldiers are sometimes given very short notice, for example, $48 \mathrm{~h}$, before they go away for long periods (Ntshota 2002:10). As a result, many soldiers have come to experience the SANDF as unaware of or unconcerned about the impact of military operations on the soldiers and their families (Van Breda 2002:7).

With reference to the above, Nathoo (1999:20) adds that the military is concerned with accomplishing its mission rather than the welfare of its staff and their families. However, the separation of soldiers and their families has negative effects on the family as a whole (Lester \& Mogil 2013), and these effects of separation during deployment are evident in the marriages of SANDF soldiers.

\section{Research methodology}

This study used a qualitative research approach to explore the emic experiences of married soldiers who were once deployed while working for the SANDF. A case study was used as a research design in order to attain the necessary information. Data were gathered through exploratory one-on-one interviews and focused group discussions. These were further supplemented by the use of literature reviews, which focused on themes relevant to the topic of the study. One hundred soldiers of different military ranks were selected. These participants were selected through a random sampling technique. 
The distribution across ranks was as follows: lieutenant colonel (LTCol) $(n=10)$, major (Maj) $(n=10)$, captain (Capt) $(n=10)$, lieutenant (LT) $(n=10)$, second lieutenant (2LT) $(n=10)$, warrant officer (WO2) $(n=10)$, staff sergeant (Ssgt) $(n=10)$, sergeant (Sgt) $(n=10)$, corporal (Cpl) $(n=10)$ and lance corporal (LCpl) $(n=10)$. The selected soldiers were between the ages of 18 and 50 years and all were living in Potchefstroom or working in the military units around the city.

No force numbers, names, surnames or initials of the members were recorded - only their respective ranks were noted.

Coding was used in place of the participants' names. The letter ' $\mathrm{M}$ ' was assigned for male soldiers, while the letter ' $\mathrm{F}$ ' was used for female soldiers. The rank of each soldier was also abbreviated to form a code. Alphabets (A-J) were used to create groups of participants with the same rank and gender. The participants were asked the following questions: state any immoral activity or activities in which you participated or that you witnessed during deployment, such as extramarital affairs or sexual harassment. Secondly, what negative effects did your deployments have on your marriage?

\section{Literature review Deployment}

Deployment refers to the period during which a deployed soldier is away from home (Laser \& Stephens 2011).

It therefore refers to the separation of an individual from his or her family for military purposes, missions and exercises such as war or peacekeeping (Ganyane 2009:n.p.; Knox \& Price 1995:1; Van Breda 2004:20). This separation affects most military personnel at one time or another as it is a demand of the job. Deployment and separation are inevitable (Suttle 2003:2). Deployment can also be defined as a temporary absence from comfort zones. It is clear from the abovementioned definitions that the SANDF is a mission-orientated organisation and its main task is to deploy soldiers where their duties are needed most at a given time. The implication of this is that soldiers enjoy the privilege of spending quality time with their spouses and families.

\section{Peace support operations and the South African borders}

In recent times, the SANDF has embarked on numerous peace support operations. Peace support operations may include peacekeeping, peace enforcement, conflict prevention, peace-making, peace-building and humanitarian operations (Wilkenson 2002:27). Allan (1991:n.p.) defines peacekeeping as a form of conflict control that restores and maintains peace.

\section{Main objectives of operations}

Ulfstein (2003:7) states that the main objective of a peacekeeping operation is to contribute to the maintenance of international peace and security by keeping the hostile parties apart and helping them to work together peacefully. Peace enforcement involves a range of coercive measures, including the use of military force in cases where the UN's Security Council has identified a threat to the peace or when there has been an act of aggression (Fagerland 2017:22). In order to reach it goals and objectives, the SANDF deploys soldiers as peacekeeping agents to restore peace during deployment missions. In addition, the SANDF deploys soldiers on the borders of the Republic of South Africa.

\section{The misconducts of soldiers during deployment}

Nibishaka (2011:5) says that South African peacekeepers deployed throughout Africa have been accused of acts of misconduct, including drunkenness, fighting in public places, promoting prostitution, sexual harassment, sexual assault and murder. Sexual harassment and exploitation is a major problem that female soldiers face while being deployed in the SANDF (Mankayi 2006:n.p.; Maughan 2006:n.p.). This is not only a major concern during deployment, but also in the units. Soldiers who commit these illicit acts not only tarnish the image of the SANDF during deployment, but also damage their own reputations, credibility and integrity before the peacekeepers of other countries and the local population.

Mandrup (2008:n.p.) adds that the behaviour of South African troops on deployment, especially off-duty troops in Burundi and the Democratic Republic of the Congo (DRC), has been a great embarrassment for South Africa. It has resulted in a force with a bad reputation.

A lack of discipline among soldiers with regard to how they treat the local population and conduct themselves has the potential of discrediting the SANDF and causing embarrassment to the entire force and country.

Moreover, it tears the entire operation apart (Mashishi 2012:9).

\section{Immoral behaviour of soldiers in deployments}

Soldiers who engage in immoral behaviour during deployment and border patrols also put their spouses and partners at risk of contracting diseases and illnesses. Their sexual involvement with multiple partners spreads HIV and other sexually transmitted diseases among local populations, putting even more people at risk (Mabuza 2010:50; O’Brien 2010:72).

Mabuza (2010:4) reveals that the members of SANDF are aware of their HIV status when they are deployed because they are expected to undergo medical tests in preparation for international deployments. The members are supposed to inform their partners of their status or to bring them to the multi-disciplinary (psychologists, social workers, doctors and nurses) team so that they can disclose their status to their partners. If this does not happen, the spouses of SANDF personnel will only find out about being infected once they are ill or pregnant (in the case of a female spouse), or when they have to sign the HIV test consent form on behalf 
of their ill or disoriented spouses who cannot give consent for treatment.

If a social worker realises that a staff member in the deployment area is HIV-positive after undergoing the process of concurrent health assessment, the social worker will ask the soldier to inform his or her spouse. The social worker on deployment will also request the local social worker at home to contact the spouse of the member to verify that disclosure occurred. Some soldiers will say that they have spoken to their spouses at home when they did not. Social workers are involved because soldiers who are diagnosed are often hesitant to disclose their status to their spouses. Many wives are concerned about their partner's sexual behaviour during deployment and the risk of HIV (Van Breda 2002:9).

Netangaheni (2001:1) reveals that military personnel are vulnerable because of long deployments, injuries, exposure to blood and being away from home. They are deployed in all provinces and to different countries and are therefore exposed to HIV and AIDS if they engage in unsafe sexual practices.

\section{The result of the deployment period}

Pitse (2009:116) mentions that marital problems have increased due to extension of the deployment period. Poku (2001:n.p.) mentions that the length of deployment has led to a situation where some soldiers start families in other countries. Some of the male soldiers have babies in the deployment territories, and these babies and mothers in the mission areas are often left without support or provision for the future (Netangaheni 2001:36). The SANDF is currently investigating allegations of sexual misconduct against its soldiers in the DRC. Five soldiers are facing paternity tests with respect to the children of four women and a young girl, who said the soldiers sexually exploited them in eastern Congo between 2014 and 2016 (Martin 2018:n.p.).

In addition to adulterous relationships, the presence of sex workers around military bases, both within and outside the borders of South Africa, is also a main concern (De Beer 2002). Bielfed (2002:n.p.) postulated that sex workers or drug dealing networks frequently operated close to bases because they knew that soldiers have adequate financial means to avail their services or purchase their products. The rape and abuse of women and young girls is also prevalent during peace operations (Mashishi 2012:9). These practices mean that many family systems and marriages become dysfunctional because of deployment.

\section{Deployment in life-threatening locations}

Jørgensen (2004:22) is of the opinion that a career-oriented soldier will probably be reluctant to decline a deployment in case this has significant negative repercussions for his or her future career opportunities. Like in any organisation, soldiers too want to progress in life. They do not want to stay in one rank for many years. A soldier is compelled to accept deployment for the sake of being promoted or to retain his or her job in the military. Soldiers are often ordered to get deployed which they cannot refuse. It is regarded as part of their career development. Ross (2008:82) mentions that personnel who are deployed in peace missions usually find themselves living and operating among the local population, who in all probability have suffered as a result of the conflict.

Therefore, military personnel perceive deployment operations as life threatening as soldiers are repeatedly exposed to gunshots. They experience inner tension or stress, which manifests in a variety of psychological and physiological symptoms (Fontana, Litz \& Rosenheck 2000:n.p.). Because of the changes in the soldiers' environment and circumstances and the resulting separation of most from their families, some of the soldiers tend to engage in risk-taking behaviour during their spare time - for example, alcohol or drug abuse and unsafe sexual behaviour that put them at risk of contracting diseases such as HIV and AIDS (Netangaheni 2001:58).

It is not unusual for members of SANDF to come together in a military bar for a few drinks after a big event like a sports match (soccer, rugby and cricket) or after completing an operation (Koopman \& Van Dyk 2012:123).

According to Koopman and Van Dyk (2012:126), peacekeeping operations have their own unique characteristics and impact on military personnel. Peacekeeping forces often face an unfriendly populace, come under fire, live in unhygienic conditions and are separated from their families. In addition, peacekeeping missions put more strain on individuals who may already be vulnerable, have a pre-existing mental health condition, suffer from alcohol abuse or are experiencing relationship problems.

Kalamdien (2008:72) stresses that during the first month of deployment, both the spouse and the deployed soldier experience feelings of sadness, isolation and abandonment. Van Dyk (2009:n.p.) emphasises the psychological challenges peacekeeping soldiers are confronted with, ranging from unexpected emotions of fear to hectic lifestyles, depression, anger and apathy.

\section{Findings}

The participants' responses to the question regarding involvement in immoral activity or activities such as extramarital affairs and sexual harassment during deployments were noted.

LTCol (M) stated that some soldiers used to jump fences to frequent places that were out of bounds or places frequented by prostitutes. Maj (M) mentioned extramarital affairs, fighting over women and women being sexually harassed by men. Capt A (M) mentioned that certain military personnel had relationships with the local women for the duration of the deployment, and they also indulged in excessive alcohol consumption. Capt B (M) stated that certain military personnel end up having affairs because they spend so much time away from home. 
Another participant, 2LT (M), said that certain male soldiers were involved in extramarital affairs with colleagues (women soldiers) and the women of the local population, while others used their power to force themselves onto the vulnerable women of the local population. Some engaged in sexual relations with women of a higher or lower rank, something of which the military disapproves. Soldiers also raped the local women, blaming their behaviour on the use of alcohol. WO2 (M) indicated that extramarital affairs are common during deployment. Ssgt (M) also mentioned that extramarital affairs occur during deployments. During his deployment, there was an incident of sexual harassment.

Cpl A (F) saw certain military personnel becoming involved in extramarital affairs, some from her section. She further indicated that during every deployment, incidents of extramarital affairs occur because of the stress level of soldiers. Cpl B (M) witnessed immoral activities, births of children, bribery and corruption. LCpl (M) witnessed infidelity during deployment.

The participants' responses to the question regarding the negative impact of deployment on the marriages of soldiers were as also noted.

Maj (M) mentioned that his wife had to cope with problems on her own. Capt (M) emphatically stated that his fiancée separated from him. He mentioned that they argued constantly because he was not there at home to assist her with their children. LT A (M) said that his wife was pregnant at the time of his deployment, and she was not happy that he was not at home to support her. LT B (M) indicated that some of the deployments are long and caused significant friction in his marriage. Once soldiers arrive in the mission area, they have limited access to communication resources (telephones) to contact their spouses. Many things happen at home that the members are not informed about.

Second lieutenant $(\mathrm{M})$ complained that he could not attend to family problems because of long channels of command that had to be followed while his family members expected of him to attend funerals and important family gatherings at home. Ssgt (M) experienced loneliness during deployments. $\mathrm{Cpl}(\mathrm{M})$ mentioned only homesickness during deployment. LCpl (M) was worried that his wife would misuse his money during deployment, and this increased his homesickness.

\section{Discussion}

The aim of this research was to critically look at the challenges that are incumbent in the deployment of married soldiers who work for the SANDF. From the general views of the participants, it is clear that deployments have significant effects on the marriages of soldiers.

Participants mentioned the following negative aspects regarding the immoral activities that were prevalent during deployments.
Soldiers often visited places that were out of bounds. Places that are called out of bounds are all places in the mission areas that pose a great danger to the lives of soldiers. Such places are known as red areas.

Commanders restrict soldiers from visiting such areas, but certain soldiers will out of their free will and lack of disciplines visit such places to socialise with the local people and to access the brothels. Others will visit such places to do unlawful businesses with the local people and other foreigners. Soldiers visit such forbidden places during the week as well as on weekends. Out of bounds places are threats to the lives of soldiers because such places put the soldiers at risk, they may be assaulted, robbed and killed by rebels and the local people. Others contract sexual diseases, and when they return back to their country, they infect their spouses.

Soldiers fighting for women: certain male soldiers will start an affair with their female colleagues during the mobilisation phase of deployment. These unlawful relationships will continue to exist during the deployment phase. Two male soldiers who are simultaneously engaged in a relationship with the same female soldier will start to argue, and their argument will result in a fierce fight. Some of the soldiers have lost their precious lives, wives and husbands because they were shot right at the deployment places outside official military activity.

Sexual harassment: this has been identified as a general aspect by many participants and it is a main concern during deployments. It is a nightmare that is not prevalent only during deployments. The repercussion of this illicit act has caused certain soldiers to be repatriated at a place of deployment without completing their tour of duty. This is a great embarrassment to the culprit, colleagues, spouse and children affected by this horrendous act committed by a soldier.

Soldiers abusing alcohol: alcohol is a commodity that the SANDF provides to soldiers in all deployments. The South African National Defence Force not only provides soldiers with food and clean water in the mission areas but alcohol is a part of the ration of soldiers. Every base has established a bar in the deployment places.

In the base there are bar hours that have been scheduled by commanders for the week, weekends, holidays, military functions and after certain big parades. Some of the soldiers will buy alcohol in the bars in bulk and store it in their refrigerators in their dwelling places. The reason for storing alcohol is that they would be able to drink after-hours when the bar is closed. Other soldiers will prefer to drink outside the base in the local community bars. The reason for drinking excessively is to alleviate their stress, to get rid of their frustrations with regard to their family problems, work-related problems and to socialise. 
Extramarital affairs during deployment: participants have identified this phenomenon as a trend during deployments. Some of the soldiers lack self-control, fidelity, virtuousness, nobleness, perseverance and resilience during deployment. That is why they will start a marital affair in the mission areas. These extramarital affairs caused some of the soldiers to divorce their spouses; others were divorced whilst they were still deployed in the mission areas.

Fraternisation: some higher-ranking soldiers are sexually involved with lower ranking soldiers during deployments. These lower ranking soldiers become dithatohatsi [the special beloved ones or queens] who are untouchable when coming to discipline, training and corrective measures. It is quite difficult for the immediate commanders and section heads to correct and subject them to tough training during the deployments. Standards of training are lowered and compromised in order to accommodate these lower ranking soldiers who fraternise with higher ranking soldiers. Some of the soldiers who are involved in these types of relationships are married men involved with married or unmarried women. Normally, these types of relationships are based on promises that have been made by higher ranking soldiers to lower ranking soldiers that if they are willing to do whatever they ask them, then they will be promoted, get contract renewals and other favours.

Incidents of rape: incidents of rape occur during deployments. It is an occurrence not just with local people, but prevalent amongst the force itself. Mashishi (2012:9) declares that rape and abuse of women and young girls is a prevalent practice during many peace operations.

Birth of children: some soldiers who are sleeping with local women end up having unplanned children in deployments. This happens whilst many local women have been left behind in deployment areas to fend for themselves and their children also grow up without knowing their biological fathers.

Participants mentioned the following negative impacts that are prevalent during deployments regarding the marriages of soldiers:

- Lack of a support system for the family: once a soldier is deployed, there is a need of a strong support from the family, relatives and the home unit. Many times in the deployments, a soldier will struggle to get maximum support from the unit that has been deployed with him or her.

- Duration of deployment: the mandate of deployments was 6 months earlier, but now it has been increased to the duration of 1 year. As the period is 1 year, it stands to reason that a soldier is unable to attend all important family gatherings, funerals of loved ones, birth of children, church matters and religious observations in order to support the spouse.

- Limited communication resources during deployment: in most cases this is the result of insufficient resources.
This will result in a poor communication with the soldiers' spouse. Pitse (2009:68) mentions that communication plays an important role in maintaining relationships. It is one means by which contact can be maintained with the member while he or she is on deployment.

- Loneliness: many times, soldiers are deployed in remote places, far away from towns and places of entertainment. Such places cause soldiers to experience homesickness and boredom.

\section{Practical guidelines to assist with deployment}

Because deployment is a project that is unlikely to disappear from the SANDF, the chaplains as pastoral figures should execute their pastoral role to ameliorate effects of deployments on the marriages of soldiers. Viljoen (2017:125) indicates that pastoral refers to the biblical background of a shepherd who is caring for his or her sheep and an analogy is often drawn between this image and the care of a Christian community. The chaplain is there to see to the spiritual well-being of the soldiers through prayers that enable the soldiers to feel at ease and comfortable to talk about any challenges (Shinga 2015:24). It should however be understood that, as Oden (1986) stated, no pilgrim can fully explain the soul's pilgrimage through various stages while the story itself is yet incomplete. Oden (1989) further argues that a person cannot be guided on the pretentious assumption that the caregiver possesses all the relevant moral knowledge. God has already been providentially present in the counselee from the outset, and has made known the divine requirement. God is already present in every rational being through the conscience and this is a capacity that cannot be arbitrarily turned off for moral self-awareness.

It is the capacity within oneself to judge oneself, to ask whether one's behaviour is acceptable or unacceptable.

To assist with the spiritual well-being of the soldiers, the chaplains should robustly come up with pastoral and ministry support plans and measures to assist, advice, and sensitize the commanders to be proactive in the deployments areas. The responsibility of the soldiers to be willing to change and cooperate fully lies with them.

On the website of AllPsychologyCareers.com it is stated that military individuals seek treatment for various reasons, such as depression, anxiety, anger management and substance abuse. The context and the demands within this context will include deployment. It is also stated on the website that this would lead to suicidal thoughts or even acts. For this reason, intense training on how to watch for signs of emotional and spiritual distress is required. Specialised educational programmes and programmes designed to dispel the stigma associated with receiving counselling should be developed.

As a first step in the process, it is the task of security officers to inform the soldiers about the out of bounds places during their presentations in the mission areas. The chaplain's role is 
to assist the security officers and commanders by preparing presentations that address the themes of responsibility, accountability, discipline and self-care.

Chaplains can also develop presentations in their support plans to address fighting in the mission areas, sexual harassment, extramarital affairs, fraternisation and rape. During chaplain periods, the chaplain should facilitate discussions based on marriage enrichment, integrity, faithfulness, assertiveness, unity and self-control. Scriptural portions that could be used with thorough exegesis for such purposes among others are the following; 1 Corinthians 6:12-20; Romans 12:9-13, 13:8-10; Colossians 3:1-7; Galatians 5:13-15; 1 Thessalonians 4:1-12; Hebrews 13:4; Genesis 13:1-9; Proverbs 5:15-22. It is accepted that these may not be the only relevant texts but these are indicated for their specific context and it could be some kind of reference that the therapist or chaplain could use to guide the soldier. A chaplain can also use these texts during the chaplain period, church services and morning parades.

Bar hours should be scheduled by commanders in the mission areas. Commanders must encourage and admonish the soldiers to drink responsibly during functions, afterhours and on weekends. Soldiers must not be allowed to buy alcohol in bulk and store it in their dwelling places; this will prevent easy access. It is understandable that soldiers would still resort to other means of getting access to alcohol, but it need not be easily accessible without control. In society, alcohol selling stores would remain open but there are some age restrictions for the buyer. This would not prevent the underaged from drinking but at least from easily accessing the alcohol. Total prohibition is impossible unless it would be determined that there is a problem of alcoholism that would need some different remedial measures. In addition to the scheduled chaplains periods it could be advisable for chaplains to arrange after-hour counselling and groupsessions for the interested groups, keeping in mind the multi-religious contexts, with special focus on spiritual development, responsible stewardship and how to keep the fire burning at home even during deployment and some other relevant topics as would be suggested by the soldiers. There should be an open-door policy implemented. A chaplain can also play a pastoral role by preparing sermons that are based on the following passages in the Bible: Genesis 9:18-28; Proverbs 23:19-21, 29-33, 31:1-9; Ephesians 5:18. Once again, these are not the only texts but could serve as easy reference in situations where therapists need at-hand scripture references.

A chaplain should advise the commanders to close the bars on Sundays. No barman should be allowed to sell liquor to soldiers on Sundays. This will facilitate time for selfintrospection, and healing to take place from all the sessions attended. People are easily influenced when they are invited or follow their peers. The guards at the gate should search every soldier and civilian coming to the unit. The chaplain together with commanders can encourage soldiers to attend church services, and chaplain periods during the week.
The social worker can work together with a chaplain to see to it that there is a support system for the family of a deployed soldier. A deployed chaplain needs to rely on the assistance of a unit which is near the family of the deployed soldier and also to have one-on-one conversations with soldiers who are deployed in order to ascertain their spiritual level, to empower them spiritually, to boost their morale and to pray with them.

The chaplain as a specialist advisor to the commander must advise him or her to encourage the soldiers during his or her officer commanding periods to organise functions, organise ranking forums to speak about their challenges, visit places that are not out of bounds and to organise music festivals in the mission areas. These events will keep the soldiers busy for the duration of the deployment. These types of activities, if planned during the deployments, will help soldiers to stay focused without stressing about the duration of deployment and will also prevent boredom.

A communication centre should be established by chaplains next to the operation room. This room can be used by the chaplain to deliver short sermons or religious announcements during the week. The social worker and psychologist will have an opportunity to interact with soldiers in the communication centre. The communication officer and the chaplain should arrange for religious books, bulletins and newsletters; distribute them in the mission area; and also send them to the spouses of the soldiers at home. The communication centre must also be developed as a media centre, where soldiers can read newspapers, use video calling, Skype, Facebook messenger, Duo and the Internet to communicate with their loved ones at home.

\section{Conclusion}

If not addressed, the effects of deployment on the marriages of SANDF members will cause irreversible damage that will result in unnecessary divorce, mental breakdown and suicide. It is therefore important that chaplains, social workers, psychologists, doctors, nurses and commanders work together as a team during deployment to support soldiers. This interdisciplinary team should be proactive and deal with social, spiritual, psychological and physical aspects before they escalate.

Soldiers are expected to uphold the code of conduct of the SANDF when deployed. They have to uphold the image of the country because they are regarded as patriots. They are not deployed merely as part of a salary-paying job, but to represent their country in a deployment area. They ought to respect themselves, their host country and the local people, especially those who are vulnerable, like women and children. A soldier can be a gregarious and philanthropic person. The primary purpose of deployment is to restore peace, protect refugees, protect citizens, to accelerate humanitarian aid and to secure the borders of the Republic of South Africa (RSA). 


\section{Acknowledgements Competing interests}

The authors have declared that no competing interest exists.

\section{Authors' contributions}

All authors contributed equally to this work.

\section{Ethical consideration}

This article followed all ethical standards for a research without direct contact with human or animal subjects.

\section{Funding information}

This research received no specific funding grant from any funding agency in the public, commercial, or non-profit sectors.

\section{Data availability statement}

Any data received from interviewees were made available to them and will also be reflected in this article.

\section{Disclaimer}

The views and opinions expressed in this article are those of the authors and do not necessarily reflect the official policy or position of any affiliated agency of the authors.

\section{Reference}

Allan, J., 1991, 'Peacekeeping in the Persian Gulf', Military Review LXXI(8), 57-63.

Bielfed, R., 2002, National survey on the knowledge, attitudes and practices of DOD members with regard to HIV and AIDS (MPI/C/2002/0006/A, April 2002), South African Military Health Service, Military Psychological Institute, Military Health Research Centre, Research Consultancy Department, Pretoria.

De Beer, J., 2002, Milestone report: A study on the experience of the use of time during operational deployment (MPI/R/516/2, August 2003), South African Military Health Service, Military Psychological Institute, Military Health Research Centre, Chaplaincy Research Department, Pretoria.

Edward, J., 1992, 'A cybernetic theory of stress, coping, and well-being in organizations', Academy of Management Review 17(2), 238-274.

Fagerland, G., 2017, 'Un-peace operations and intelligence. Can the Joint Mission Analysis Center succeed?', MA thesis, Norwegian Defence Command Staff College, Norway.

Fontana, A., Litz, B. \& Rosenheck, R., 2000, 'Impact of combat and sexual harassment on the severity of post-traumatic stress disorder among men and women peacekeepers in Somalia', Journal of Nervous and Mental Disease 188(3), 163-167. peacekeepers in Somalia', Journal of Nervous and Mental
https://doi.org/10.1097/00005053-200003000-00006

Ganyane, E.M., 2009, 'Gender differences in salutogenic functioning in military deployment', MA thesis, University of South Africa, Pretoria.

Jørgensen, T.M. 2004, 'The peace support capacity of the South African armed forces', draft paper presented for DoDR's Seminar Series Lecture, Pretoria, 01 September 2004.

Kalamdien, D.J., 2008, 'A psychological support programme for peacekeeping soldiers and their families: A model for discussion', in G.A.J. Van Dyk (ed.), Strategic challenges for African armed forces for the next decade, pp. 38-102, Sun Media, Stellenbosch.

Knox, J. \&. Price, D., 1995, 'Citizen-soldier families: Opportunities and challenges for social work', paper presented at the annual conference of the National Association of Social Workers, 15 October, Philadelphia, PA.

Koopman, R. \& Van Dyk, G., 2012, 'Suicide prevention and management in the South African National Defence Force: A psychological discussion', Militaria: South African Journal of Military Studies 40(1), 117-138. https://doi.org/10.5787/40-1-987
Laser, J.A. \& Stephens, P.M., 2011, 'Working with military families through deployment and beyond', Clinical Social Work Journal 39(1), 28-38. https://doi.org/10.1007/ s10615-010-0310-5

Lester, P. \& Mogil, C., 2013, 'Children and families', The Future of Children 23(2), 121-141. https://doi.org/10.1353/foc.2013.0015

Mabuza, P., 2010, 'The impact of HIV serodiscordancy on married couples attending the infectious disease clinic at 1 military hospital', MA dissertation, University of Pretoria, Pretoria.

Mandrup, T., 2008, 'The South African National Defence Force: Midwives of peace in Africa? An evaluation of SANDF involvement in peace support operations', in L. Leroux (ed.), South African Army Vision 2020, vol. 2: The South African Army, relevant and ready for future security challenges in Africa, Institute for Security Studies, Brooklyn Square, Pretoria.

Mankayi, N., 2006, 'Male constructions and resistance to woman in the military', Scientia Military: South African Journal of Military Studies 32(2), 44-64.

Martin, G., 2018, SANDF takes further action against sexual abuse, viewed 12 September 2018, from https:/www.defenceweb.co.za.

Mashishi, K., 2012, 'Cultural intelligence: SA army in peace operations', Thaba Tshwane, 15 August 2012

Matjeke, K., 2017, 'Factors influencing work satisfaction of single parents in the South African National Defence Force: An exploratory study', MA thesis, University of Stellenbosch, Stellenbosch.

Maughan, K., 2006, 'SANDF peacekeepers face litany of sex charges', Pretoria News, 04 November, p. 1.

Moelker, R. \& Van der Kloet, I.E., 2003, 'Military families and the armed forces: A twosided affair?', in G. Caforio (ed.), Handbook of the sociology of the military, pp. 201-223, Kluwer, New York.

Motumi, N.E., 1999, Military social work practice model, Directorate Social Work, Pretoria.

Nathoo, T., 1999, 'Deployment-related stress: The experience of naval families', MA dissertation, University of Natal, Durban.

Netangaheni, T., 2001, 'The exploration of perceptions of people regarding HIV/AIDS in the workplace', MA dissertation, University of South Africa, Pretoria.

Nibishaka, E., 2011, 'South Africa's peacekeeping role in Africa: Motives and challenges of peacekeeping', Rosa Luxemburg Stiftung, Johannesburg.

Ntshota, N., 2002, Challenges facing married couples in the deploying units of the South African National Defence Force, University of Cape Town, Cape Town.

O'brien, M., 2010, 'National and international criminal jurisdiction over United Nations peacekeeping personnel for gender-based crime against women', PhD thesis, University of Nottingham, Nottingham.

Oden, T.C., 1986, Crises ministries, Crossroad, New York.

Oden, T.C., 1989, Pastoral counsel, Crossroad, New York.

Pitse, C.A., 2009, 'Spousal Support in the South African National Defence Force during External Military Deployment: A model for social support services', PhD thesis, Department of Social Work and Criminology, University of Pretoria, Pretoria.

Poku, N., 2001, 'The crisis of AIDS in Africa and the politics response', in Poku, N. (ed.), Security and development in Southern Africa, Greenwood Press, Westcort, Connecticut.

Ross, C., 2008, 'South African perspective on pre-deployment mission readiness: Preparation of personnel to be deployed in peace missions', PhD thesis, University of Pretoria, Pretoria.

Savych, B., 2008, 'Effects of deployments on spouses of military personnel', PhD thesis, Pardee Rand Graduate School, Santa Monica, CA

Shinga, G., 2015, 'Factors involved in combat readiness with hardness as a mediator: An exploratory study', MA dissertation, University of Stellenbosch, Stellenbosch.

Suttle, J.E., 2003, 'Hot topics-current issues for army leaders: Reunion putting the pieces back together', Preparing for a Happy Reunion, Communication, Re-Establishing Intimacy 5(3), 1-16.

Ulfstein, G., 2003, The legal basis for the use of force by UN peacekeeping operations, viewed 11 September 2018, from https://www.duo.uio.no/.../Peacekeeping.

Van Breda, A., 2004, 'Multicultural scale development in social work', MA dissertation, Rand Afrikaans University, Pretoria.

Van Breda, A.D., 2002, 'Social concerns for peace support operations', paper presented at the 34th International Congress on Military Medicine, Sun City, South Africa, 15-20 September 2002.

Van Dyk, G., 2009, 'The role of military psychology in peacekeeping operations: The South African National Defence Force as example', Scientia Military, South African South African National Defence Force as example, , Scientia Military, South Afric
Journal of Military Studies 37(1), 113-135. https://doi.org/10.5787/37-1-62

Viljoen, J., 2017, 'Life-coaching within the context of pastoral theology', PhD thesis, North-West University, Potchefstroom.

Wilkensons, P., 2002, Peace support operations: A working draft manual for African military practitioners, Institute for Security Studies, Pretoria.

What is military counselling and why do we need it, viewed from https://www. allpsychologycareers.com/topics/military-counseling.html. 